DOI 10.18551/rjoas.2019-06.14

\title{
TERRITORIAL MARKETING AND COLLECTIVE BRANDING TO SUPPORT REGIONAL DEVELOPMENT: A STUDY OF SMES BATIK INDUSTRY
}

\author{
Roostika Ratna \\ Faculty of Economics, Universitas Islam Indonesia, Indonesia \\ E-mail: ratna.roostika@uii.ac.id
}

\begin{abstract}
Global competition places more challenges not only for nations but also regions to attract potential resources. Marketing approaches have been pursued by the government and the local authority to communicate their places. The aim of this study is to analyze the implementation of territorial marketing and collective branding to support regional development. Region or territory has its own identity and uniqueness that can be used as a tool to differentiate from the competitors (other regions). More specifically, this study explores the process of building collective branding in Batik clusters located in Banyuripan, Bayat, Klaten Central Java Indonesia. Case study analysis and focus group discussions were conducted to gather and analyze the data. Four batik clusters were chosen as case study. The main objectives for this case study analysis are: 1) Finding the standard quality batik production. 2) Producing standard operation procedures to support collective branding. 3) Socialization of territorial marketing and implementation of collective branding. 4) Collective branding registration for Batik Banyuripan.
\end{abstract}

\section{KEY WORDS}

Territorial marketing, collective branding, regional branding, batik industry.

With the increase on global competition, branding a place has become increasingly a common strategy for the government and the local authority. Linking marketing strategy and place management is no longer a new phenomenon. The use of branding is to communicate the identity and uniqueness of the place. Some success examples of city and nation brands are "I Amsterdam", "Be Berlin", "I Seoul U" for city brands, as well as "your Singapore" and "100\% pure New Zealand" for country brands. Branding the place expresses the marketing and entrepreneurial efforts of the government, where place is now managed more like business manner (Harvey 1989; Kavaratzis 2005). Despite nation and city branding, place branding strategies are also applied in smaller economic sectors for the same reasons. Place branding can be employed on different scales of geographical areas (nations, state, territory, regions, cities and communities). Branding for smaller areas such as regional or territorial branding has also been seen as effective in marketing local products and strengthen the local identity. The introduction of geographical indications (Gls) highlights the proliferation of combining the image/reputation of the region or territory with the local products.

Geographical indications or Gls is naturally the kind of brand strategy. Unlike the common brand, it does not explicitly indicate the firm/single owner of the brand. Developed by EU countries, Gls branding combine the name of the location to the product as a brand name. One particular product often is very well known from specific area and it cannot be easily produced in other areas. Gls branding has been developed to guarantee the quality and originality of the product along with the geographical location as part of the brand. Gls branding strategy was initially applied for agricultural and food products, but nowadays, it has expanded to more varieties of local products. The main objective of Gls idea is to protect the producers and consumers from fraudulent use of the product name. Products that have been successfully protected by Gls are wine, spirits and foods (chocolate, cheese, coffee and tea).

Although nations have been commonly used as the usual unit of analysis when examining economic growth, economic performance between regions within the same country is different (Borg 2013). Some regions are more prosperous and grew much faster than other regions (Lorenzinni 2011). Some regions may also more popular than the country 
it self. The popularity may because of the unique landscape, culture, history, tourism infrastructure and the local products. The Gls idea relates more on the local knowledge, innovation and resources that has evolved in a long period. This phenomenon makes it important to investigate the relation between the image strength of the location and the local products produced. Due to the majority of the local producers are local farmers or local small medium enterprises, thus they need to be protected by the government. Creating Gls system is to ensure that the local original producers are protected and may compete well with their distinct brand name in the global market.

Rural regions are competing with their neighboring regions and other regions. Places are competing for "scarce resources". Scarce resources include tourists, companies and talented people, investors, event, etc. The success of place branding requires local competences, availability of distinctive assets and resources. In rural areas, agricultural and food products often form a distinctive assets. This local distinctive assests can also built from the local talents and local culture to make arts and crafts. To communicate and protect the local products, the local authorities are now taking marketing approach to improve the performance of the local industry. The aim of this applied research is to explore how the practice of territorial marketing and collective branding may support regional development. Specifically, this study will analyse the case of collective branding practice effort in Batik clusters in Banyuripan, Klaten Central Java Indonesia.

\section{LITERATURE REVIEW}

Territorial marketing according to Gollain (2013) in Amajid, et al., (2016) is public management area which considers the efforts to build the territory to become more competitive than the other territories, including promoting territoriy's offering to target market. Success from territorial marketing is expected to attract more talented people to stay and visitors to come thus increasing the territory's income and quality of life. Territorial marketing is defined as a tool to manage a territory by developing its resources through promoting its services, goods and activities of people and business operating there (Amajid, et al., (2016). In the field of place management, there are resources, called as 'scarce resources' which are competed by all places. Scarce resources include tourists, skilled or talented people, students, investors, events, firms, etc, which have the potential to generate the wealth of the territory. All efforts are often focused to call these scarce resources to come to the area since these scarce resources when managed well can be a potential booster for economic development. Hatem (2007) in Amajid, et al., (2013) divided the target of territory marketing into three categories. 1) investors, to attract funds to establish commercial relations nationally and internationally, 2) tourists for offering income and new experiences, 3) citizens in order to strengthen identity, quality of life and sense of belonging. The challenge of territory marketing is to create positive image that the place is attractive to live and to invest. Overall, the main objective of territorial marketing is the wellness and prosperity of the people in the territory.

The concept of country-of-origin (COO) has long been in the discussions in the marketing literature. Here the product is connected with the country's reputation. Globalization of the market makes particularly developed countries win the effect of COO. $\mathrm{COO}$ which recently also known as Place-of-origin (POO) is an effective marketing strategy in combining the strength of country reputation to any products made by the related country. Some countries are very successful with the COO concept for example Japan with its car and electronic industry, The US with its car, computer and film industries, Italy with its car, shoes, bags, and Korea with its mobile phone, car and cosmetics. The correlation between place and its product has become the strength in marketing and place development strategy.

Until now, studies on nation branding / marketing, place branding / marketing, city branding / marketing have largely treated in the literature within multidiscipline backgrounds such as marketing, urban planning, public diplomacy and economic development (Anholt 2002; Anholt 2006; Dinnie 2008; Kavaratzis \& Ashworth 2005, Braun, \& Zenker, 2010). All these studies emphasize that places are competing for resources in order to prosper people 
who live in the area. Place can use the marketing approach compete and win the market. All nations are developing brand and conducting marketing strategy to communicate their identity and promote their offerings. Regional authorities are also building their local brands to win the scarce resources. With the advanced of information technology, the effect of place branding and marketing are more effective since technology helps the places to reach their targeted market faster.

However, place branding study for regions has been rather neglected (Florek, 2013). Only a few studies have investigated the regional product or regional branding in relation to place branding or place image (Elliot \& Papadopoulos, 2016) and regional branding to local cooperation and sustainable development (Florek, 2013). Few studies on regional branding are studies by Garcia, et al. (2013) and Pasquinelli (2010), which observed the capacity of regional branding to support local development. the major conclusion of that studies are the importance of well coordination and cooperation of different local stakeholder groups on regional branding efforts.

Food has been so far the most advanced product introduced with the regional/territorial branding. For example, the European Union has developed a common legal framework for official signs to agricultural and food product quality related to their origin. This legal framework known as Geographical Indications (Gl) which consists of three types namely protected designation of origin (PDO), protected geographical indication (PGI) and traditional specialty guaranteed (TSG). The World Trade Organisation (WTO) so far has acknowledged Gls as intellectual property rights and having the same basis as those of other commercial brands (Trade-Related Aspects of Intellectual Property Rights, TRIPs Agreements 1994). Some agricultural products from USA and EU that have gain popularity in implementing GIs system are Florida oranges, Idaho potatoes, Washington apple, Scotch Whisky (UK), Asiago cheese (Italy) and Bordeaux wine (France).

When branding regional food, commonly the branding efforts are connected with the local culture and heritage. How the food is locally produced, how the food is locally consumed as part of the tradition, and how the food is supporting the local's economy are all effect the formation of regional branding. Regional food branding is a complex process since it has some multidimensional aspects that provide identity for the food. Lorenzini et al., (2011) stated that territorial brands consider emotional and iconic brands, and should be able to convey an authenticity, quality and typicality of the product, represents the contexts of the rural traditions and having strong commitment from the locals to materially and immaterially treating the brand. This means that despite the distinct features of the local product, the locals are also actively engaged with the products.

Porter (2003) argues that even though economic development is usually measured per country basis, however, it is common that some regions in the country may have better reputation than the country it self while also the economic performance of the regions are different. A region could be very prosperous due to the geographical locations and the talented locals. Regions with rich cultural heritage and local talents may leads due to the active participation of the locals. Regional branding can be given for non food products such as arts and crafts (painting, dance, pottery, batik, etc). The abilities of rural people combined with the local natural resources may create distinctive local products. Branding local product can be in the forms of individual or group. However, individual branding tends to be organized by a more established firms, while SMEs usually do not consider branding their products. While the benefit of branding and giving legal entities is very important for future global competition, collective branding is one alternative to support the local SMEs to improve their competitiveness.

Brand is a name, term, design, or symbol of a company or organization or producers to differentiate or give identity to their products or offering from others (Fishman, et al., 2018). Brand has many benefits to either the producers and the consumers. The benefits for producers cover giving the identity and protections. For customers, brand communicate the quality, distinctiveness, reduce risks and social status. For the producers, when competing in the wider market place, brand provide legal protection from activities such as irresponsible illegal use or property right (Suryo, 2010). Collective branding is sharing a brand by a group 
of producers. Collective branding is a name for certain products / services which is traded by group or individual. This collective branding has been practiced by some countries who has applied Geographical Indications (Gls) system such as for wines (Bordeaux, champagne), cheese (Camembert, Parmesan, Feta) and cofee (Colombian, Ethiopian). These brand names have been protected with geographical indication (PGI) status meanings that others are restricted the use of the geographical identication unless the product are made from the area. In order to create distinctiveness of the local business, using the concept of Gls, the protection of local skills can be embedded with the geographical name. The Gls concept allow rural resources with geographical name to be developed by the region using marketing strategies emphasized on distinctive identity (Horlings \& Marsden, 2014).

Regional products commonly have a long history and may have a strong emotional value related to the original location where it produced. The need for producers to distinguish their local products through non-price factors such as place of origin, product quality and image has becoming more critical due to intense competition and the business opportunity for the market who appreciate the value of authenticity. For local producers (SMEs) their limitation to build individual brand can be overcame by collective branding. The sharing name by groups of producers may assist 1) providing legal protection, 2) providing clear identity, 3) sharing knowledge and talent, and 4) maintaining quality standards. When the geographical name is used for collective branding, this strategy will strengthen the identity and becoming more difficult to copy by competitors.

\section{METHODS OF RESEARCH}

The case study was chosen as a research strategy. The case study focused on collective branding effort by Batik cluster located in Banyuripan, Klaten, Central Java Indonesia. These batik clusters have specialty in their hand made batik production with natural color. In order to achieve the objective of the study, field studies were conducted to four batik clusters in the targeted areas. Some interviews to local authorities were also completed to understand how local authorities managed their marketing strategy. Java is the island where batik has well developed until recently. Around Banyuripan area, there are four active batik clusters where each cluster is supported by 25-45 women entrepreneurs as members. Four batik clusters were visited twice in order to: 1) see in detail how batik is made, starting from how raw materials are bought, designing, waxing, soaking, airing, administrative, quality control, ordering, marketing, financing and training. 2) Socialization and training to introduce and ensure for the standard quality in production. 3) Arrange standard operating procedure for quality control. 4) preparation and management of the clusters for collective branding registration and implementation.

The member of batik clusters in Banyuripan are all family small businesses. Some of the women entrepreneurs are quite advanced in managing the business where they already have their own show room in their house. However, they don't individually name their production since they are belonging to the clusters. They are allowed to sell their batik production individually and directly to the market, but somehow the order is higher from the group clusters. The clusters regularly have a meeting once a month to discuss some issues or managing routine orders. The name of the group of batik cluster "Batik Banyuripan" has been accepted by all members in the cluster. However, they do not aware of the importance of legalizing the brand name. Due to the situation where the name "Banyuripan" is shared or used as collective brand, thus the alternative strategy is registering the brand "Banyuripan" to the government via the ministry of law and human rights. It is important that all members of the cluster understand whether the name "Banyuripan" is going to be registered. Once registered as a collective brand, all members must have the commitment to maintain the level of quality as agreed by all of the members.

In complement with field survey, focus group discussions (FGD) were also taken to gather more information from the member of the batik clusters and from the local authority invited to the meeting. The topic for the first FGD was a discussion on challenges and problems in batik natural color productions. Other than sharing inormation from FGD, 
researcher and the team are also gathered information relating to required quality standard for batik natural color production. This information is further prepared for arranging the standard operating procedures (SOP) to be distributed among the cluster members as guidance for quality control.

The second focus group discussions was conducted with the emphasized on the following topics:

- Good governance. Even though the clusters combined is considered as small medium enterprise, however, quite often that the group received huge amount of orders, where all members received responsibility to handle the project together. This means that there should improvement on the organization management, particularly the definition of job responsibility. The group must arrange clear job divison so job responsibility is clear and the work load is distributed evenly;

- Financial report. A well managed financial report is important for the investors to value the prospect of a business. Similarly, if this cluster wants to expand and needing investment, financial report must be clearly provided. Financial report is also important as the form of organisational responsibility to its members;

- Intelectual property and collective branding. The members of Banyuripan batik cluster are majority house hold women with education as high as high school graduate. Only few of them with university degree. In the rural areas, collective living is very strong and many way of lifes are shared together. Intelectual property right is a kind of knowledge they do not have many information on it since they have not found the urgency for their business at this current state. In the future, everyone must appreciate their talents, their works and their productions, as part of the competition to stay in the business. Knowledge of intelectual property right will protect someone's creations and teach people to respect on someone's creations;

- Collective branding. The knowledge on collective branding is very urgent since the clusters' logo is yet being registered to the authority. The similar name and logo could be used and registered by others and thus no more chance to use the same name and logo for this group of cluster. The current name of the clusters is "Banyuripan" batik. This name is originally come from the geographical name "Banyuripan" region, where this group of cluster is geographically located. Branding product by attaching the geographical name has been acknowledged in the Gls system and can be a good identity for branding collective producers. Batik producers can use the Gls approach in naming the brand since it provides identity while also Batik entrepreneurs will take a lot of benefits from joining the collective branding. As a small family business, there is a small potential that the batik women entrepreneurs will set up individual brand. Collective branding is one of solution to protect their products.

\section{RESULTS AND DISCUSSION}

Batik as a Javanese word 'amba' means 'to write'. Indonesian's batik has a long history and Indonesia is the biggest country that maintain the design and technique to make Batik. Batik is particularly very popular in Java and there are three kinds of batik techniques, which are 1) hand-written batik, 2) hand-stamped batik, and 3) combination of hand written and stamped batik. Indonesian batik has been part of Indonesian culture since the $4^{\text {th }}$ or $5^{\text {th }}$ century. Batik as local cultures have been practiced long before the foreign influence entering Indonesia. For the Javanese, the design of batik has many symbols representing the human life cycle from the birth stage, marriage life and the death. The motifs and designs have been majority influenced by the nature such as the animals, leaves, flowers, clouds, etc. Until recently, Indonesian's batik is produced by different size of businesses, whether Individual SMEs, firms and/or group of clusters.

Culture can be a strategic factor that supports the economic development, social capital and the quality of life (Simeon \& Martone, 2014). As a cultural product, the work on Batik is sought for its authenticity which is made through combinations of social distinctiveness and cultural characteristics (Park, et al., 2016). Batik consumers appreciate 
the authenticity and would be willing to pay premium for valuing the authenticity. Authenticity can be valued in terms of the motifs and designs, the detail complexity, the production methods and the place of origin (Beverland \& Farrelly, 2010). Spreading in vast geographical locations, Indonesian batik has varieties of designs and dye techniques. Despite the varieties of batik production across Indonesia, the center of batik production remain strongly from Java particularly centering around Central java (Surakarta, Yogyakarta, Pekalongan), West Java (Cirebon), and east Java (Tuban, Lasem and Madura). There are currently 3,400 batik designs have been developed in Surakarta Central Java and until 2008 there has been 900 batik designs patented from Batik Surakarta (Kemendag, 2012). The growth of batik industry as well as the pride with batik arts have been increasing sharply after the announcement from the UNESCO, in the $2^{\text {nd }}$ of October 2009, where Indonesian Batik was designated as a Masterpiece of Oral and Intangible Heritage of Humanity. Since then, the $2^{\text {nd }}$ of October is celebrated by Indonesian as national Batik day.

After listed as cultural heritage by UNESCO in 2009, the market attractiveness and popularity of Indonesian batik is increasing sharply. As a cultural product, the market appreciate authenticity and consumers are willing to pay premium price (Moulard, et al. 2015). However, there is a consequence due to the popularity of batik in the market where "Batik printing" since then flooding Indonesia's textile market. Batik printing is a kind of textile with batik motifs printed on it. Indonesian does not consider batik printing as Indonesian's batik, it is only a common textile product. Majority of batik printing comes from China and Malaysia (Sardjono, et. al., 2015). Even though Indonesia's batik export increased, import batik also increased from USD 28 million in 2014 to USD 34 million in 2015 (Budiman, 2016). Due to the ease in production using the machinery technology, the price of batik printing is far cheaper than the local manual handmade batik. The number of batik printing competing in Indonesian batik market certainly worries local batik producers since Indonesians' consumers are not quite aware of batik printing and batik handmade while also consumers enjoy cheap batik. Only those who have concern in the value of traditional batik will appreciate the hand made batik. After all, this imported Batik is certainly destructive to the competitive capability of the local Batik. Government need to take action to protect the local Batik.

While the designs can be easily copied, the hand drawn and stamp Batik are still valued due to its uniqueness and authenticity of the making. To protect the traditional batik, one of the solutions is by giving them legal protection. Batik design and the motifs are rich with intellectual properties. Branding the local batik should be managed to protect from the imported Batik. The benefits of branding or giving trademark for local batik covers: (1) Providing identity to distinguish between local batik and imported Batik. 2) providing distinguished mark which represent the quality of the product. 3) Helping the promotion of local Batik. 4) providing legal protection. In order to receive collective branding or trademark, the producers should register their brand to the Directorate General of Intellectual Property Rights of Indonesia (DGIPR Indonesia). In the case of SMEs where branding is uncommon and too expensive to cover the cost, the solution is by organizing collective brand. The collective brand can be used by the members of the group when doing their trading activities. In becoming the member of collective brand, all members must agree the terms and conditions for committing the quality standard.

The Modern batik has taken place since the influence of Islam and western countries. The modern designs have less traditional guidelines and have more freedom in expressing motifs and colors. More chemical coloring instead of traditional (natural) coloring is currently used and environment consequences become the further issue. As the coloring technology improving, batik is drawn in more varieties of medium, such as in wood, glasses, metal, etc. Batik designs and motifs are also creatively expanding to be produced for mobile phone wallet, laptop covers, helmet, wooden statues, house hold clothes, t-shirts, stationary items, accessories, etc. The authenticity of modern batik products similarly needed to be protected. Once the design or the idea is launched to the market, it will soon face industry competition particularly copying issues. In the creative industry which rich with intellectual property 
issues, producers and artisans should understand how to protect their talents and their products to sustain competitive.

In the context of rural SMEs such as women batik entrepreneurs in Banyuripan, Bayat, Klaten, many are unaware from the importance of protecting their products and creativities. If the government were not taken care, they will hardly survive. The introduction and registration for collective brand is considered urgent since the business has increasing orders from national and international clients. If they were not protected, their local name (Banyuripan as geographical name) could be registered by others and the group will miss the chance of using their local geographical name as their local identity. Registering the brand name is not the domain of individual SMEs since it is considerably expensive and time consuming. It is therefore more cost effective when collective branding is agreed and managed by the group.

Our research team in the second FGD has gathered the information about the acceptance of participating to the collective branding. There has been some positive response by the cluster members since they have some experience on having their designs spread quickly by others before they have the chance to introduce their own motif design to the market. The brand provides identity and creates positive image in the eyes of consumers (Fathanudien, 2016). Collective branding not only protect their brand name "Banyuripan" but further may be extended into registering all motif designs that need to be protected. When joining with the collective brand, there are certainly some rules that all member should comply with the term and conditions agreed. The terms and conditions for collective brand commonly cover: product characteristic; general features; monitoring procedures; quality standard; sanction or penalty.

Once the terms and conditions have been arranged and agreed by all the members, the group or organization may apply to the ministry of law and human right. With the case of "Banyuripan" name as a collective brand name, in doing registration, some members as representative could sign the document. Once approved, the organization is no longer run by a person but by all member listed in the collective brand document. Some benefits from registering collective brand cover: 1 ) the costs (price) is shared together (not by individual), 2) the difficulties in running the business are shared, 3) the skills and knowledge are shared, 4) the market and projects are shared and distributed together, 5) the production processes can be shared, 6) the marketing effort can be shared, and 7) instead of competing, the members support each other.

The success of collective brand depends on the commitment of the member. The mutual cooperation or in Javanese term called 'gotong royong' should be encouraged among members. The strong cultural characteristic combined with geographical reputation will give identity and uniqueness in distinguishing 'Banyuripan natural color Batik' from competitors. All members in collective brand may use the brand name and logo for their business operation. After in depth discussions with representative members of batik Banyuripan clusters, a logo was designed and the meaning was given to the logo. Together with the brand name "Banyuripan", the logo also registered to the ministry of law and human right. The batik Banyuripan logo is described in figure 1, where the green color represents the symbol for commitment of using natural color. The picture "canting" which is a specific spoon to place the wax when drawing batik represents the nature of hand made traditional batik techniques used. Bayuripan collective brand has been registered to the office of local ministry of law and human right in March 2019. Once registered, "Banyuripan" as a collective brand name and the logo are now legally protected by the Indonesian government and will be valid for 10 years. The name and logo should be re-registered after 10 years have passed.

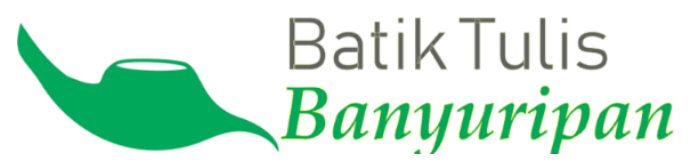

Figure 1 - Banyuripan Brand Logo 
Traditional Batik can be made in three techniques: Hand written Batik, hand stamped and combination of the two. Wax is used to draw batik using special tool called "Canting". Invented by the Javanese, canting is a small copper container as drawn in Banyuripan logo. The tip of canting has different sizes of spouts. Different size is used to create varied design effects. The wax is heated on the small stove, and the liquid wax is placed in canting then is used to draw batik motifs. After waxing the motifs, there are several steps to be followed which are waxing and dewaxing (removing the wax). This waxing step can be done several times depending on the expected color and detail motifs to the fabric. The traditional motifs are still produced and easily found in the market with softer colors. The modern batik commonly used chemical with brighter colors and more varieties of motifs and designs.

The making of hand drawn Batik can take several days, weeks and even months particularly for a fine quality hand-drawn batik. No wander hand drawn Batik is very expensive due to the difficulties and time-consuming efforts in making it. With the growing demand of Batik, the stamped Batik was introduced. The stamped Batik is particularly to make Batik more affordable for lower income people as well as more speed in the making. Since batik demand is quite high, another technique was introduced called hand stamped batik. This technique is similarly using melted wax, but instead of written into the fabrics, the wax is applied into the cooper stamp. The stamped batik was introduced in the $19^{\text {th }}$ century. The stamped technique allows the production of high-quality Batik with shorter time. The stamped technique takes 2 to 3 days to complete. This stamped technique is done by both women and men, and it is easier than the hand written batik which usually done by women. Stamped batik is cheaper than hand written batik. However, the combination oh hand written and hand stamped batik is also common techniques and many combination products are found in the market. The price of course is more expensive than the pure stamped batik.

Globalisation makes all countries, government and individu reachable and competitition is at all levels. The early marketing literature has identified on the role of Country-of-origin / $\mathrm{COO}$ in increasing the competitiveness of products from related country of origin. However, there are different growth and performance among regions in the country. Some regions may be better developed than other and may be more popular than the country where it resides. Such as Bali for Indonesia, many overseas tourists know Bali as famous destination better than Indonesia. This condition make sense when the reputation of a region/territory can be a powerful marketing tool to increase the market of the regional product. As previously discussed, territorial marketing is the action to manage territory's resources through marketing local goods and services operating in the territory. In order to be able to be marketed and receive positive market response, local products should be branded. Product brand will be useful to support the region marketing strategy. If a territory have rich of local industries, these industries can be a big asset to promote territory. When local industries has regsitered brand, the regional marketing team will be easier in communicating the identity as well as the distinctiveness of the local products.

When planning and conducting territorial marketing, policy makers should do prior analysis about the history of the place, the daily life of the people, the characteristics of the citizens, the natural resources (raw material) as well as the local culture that determine the uniqueness of the area. Among" territorial marketing, collective branding, culture and local daily life", they should be well managed in order to create strong identity to the local. With the better economic condition, people around the world have better income and this impact on more people travelling. When travelling, people usually enjoy the place which offer uniqueness they cannot find in their home countries. Even that travellers would be happy to pay high for something that unique and having good quality. Originality and authentciity become important value seek by more people regardles the higher costs that traveller should pay. Creating uniqueness and originality are now important strategies to marketing territory. The internet helps people to do in deepth search for products or destinations they wish to visit. To market territory and support collective barnding, online and offline approach should be endorsed and the market dynamic should be anticipated regularly. Overall, the success of local branding and territorial marketing is closely related. Government or travel agents should 
build marketing strategy for the territory, where the local products and local brand are clearly promoted and communicated.

\section{CONCLUSION AND RECOMMENDATIONS}

Global competition placed more challenges to any organization whether profit or non profit to sustain. Not only business entities that needs to apply marketing approach, but also governmental bodies at national or regional level face competition to make their place prosperous and attractive to the stakeholders. Regional development can be achieved when the region has significant resources to support the growth of the area. These resources known as scarce resources are competed among regions. These resources cover investment, investors, events, tourists, skilled and talented people, students, etc. In managing and attracting scarce resources to come, regional government needs to market and promote its place. One of the challenges in managing resources is protecting the resource with brand and engaging in specific marketing strategy. Region or territory has its own identity and uniqueness that can be used as a tool to differentiate from the competitors (other regions). The challenges in creating this differentiation effect are by understanding the strength of the local products. When branding local products, the combination of the uniqueness of the products and the geographical name can be an effective regional marketing strategy. The aim of this research is analyzing how the practice of territorial marketing and collective branding may support regional development. Due to the limitation of local producers to set up individual brand, the alternative strategy is by assisting them to build collective branding. This study explore and analyse the process of building collective branding in Batik clusters in Banyuripan, Bayat, Klaten Central Java Indonesia.

Batik Banyuripan is a Batik cluster focusing the production with hand written batik using natural color. The member of this cluster is women Batik entrepreneurs. The uniqueness of Banyuripan batik is the specific garden design and the natural coloring which has minimum pollution impact to the environment. In order to success in the regional branding and territorial marketing, the local products should be supported. Using the Geographical Indication approach, this batik clusters registered their Banyuripan name and logo as collective branding. This batik cluster brand and the local products could be one of the assets for the regional branding in Klaten region. In order to support the sustainability of production and the quality standard, the members of Bayuripan collective brand have to agree with the terms and conditions. Training and monitoring are given to ensure that the output will always within the quality standard required.

\section{REFERENCES}

1. Amajid, G., Souaf, M. \& Wazani, Y.E. (2016). Territorial marketing and its effects on Development, approach from the literature. Revue Marocaine de recherche en management et marketing, 13, January-March, 111-129.

2. Anholt, S. (2002). Nation branding: a continuing theme. Journal of Brand Management, 10 (1), 59-60.

3. Anholt, S. (2006). Public diplomacy and place branding: Where's the link? Place Branding and Public Diplomacy, 2 (4), 271-275.

4. Beverland, M.B. \& Farrelly, F.J. (2010). The quest for authenticity in consumption: consumers' purposive choice of authentic cues to shape experienced outcomes. Journal of Consumer Research, 36(5), 838-856.

5. Braun, E. \& Zenker, S. (2010). Towards an integrated approach for place brand management. 50th European Regional Science Association Congress, Jonkoping, Sweden, 19-22 August 2010.

6. Borg, E. (2013). Collective Brand Strategy, Entrepreneurship and Regional Growth: The Role of a Protected Designation of Origin (PDO). Journal of World Economic Research, 2(3), 26-38. 
7. Budiman, D. (2016). Karena Murah, Masyarakat RI Lebih Suka Batik Palsu Buatan China. Available at https://economy.okezone.com/read/2016/02/25/320/1321075/karenamurah-masyarakat-ri-lebih-suka-batik-palsu-buatan-china

8. Dinnie, K. (2008). Nation branding: Concepts, issues, practice (London: Routledge).

9. Elliot, S. \& Papadopoulos, N. (2016). Of products and tourism destinations: An integrative, cross-national study of place image. Journal of Business Research, 69, 11571165.

10. Fathanudien, A. (2016). Alternatif perlindungan hukum atas hak merek kolektif genteng Jatiwangi guna mengurangi persaingan usaha di Kabupaten Majalengka. Jurnal Unifikasi. 3 (2).

11. Fishman, A., Finkelstein, I., Simhon, A. \& Yacouel, N. (2018). Collective brands, International Journal of Industrial Organization, 59, 316-339.

12. Florek, M. (2013). Building the image of a place brand with the support of local commercial brands. Poznan Brand Consortium case study. Journal of International Studies, 6(1), 9-21.

13. Garcia, M.D.D., Horlings, L., Swagemakers, P. \& Fernandez, X/S. (2013). Place branding and endogenous rural development. Departure points for developing an inner brand of the River Minho estuary. Place Branding and Public Diplomacy, 9 (2), 124-140.

14. Harvey, D. (1989). From managerialism to entrepreneurialism: the transformation in urban governance in late capitalism. Geografiska Annaler. Series B. Human Geography 71B (1), 3-17

15. Horlings, L.G. \& Marsden, T.K. (2014). Exploring the 'New Rural Paradigm'in Europe: Eco-economic strategies as a counterforce to the global competitiveness agenda. European Urban and Regional Studies, 21 (1), 4-20.

16. Kavaratzis, M. \& Ashworth, G.J. (2005). City branding: an effective assertion of identity or a transitory marketing trick? Tijdschrift voor economische en sociale geografie, 96 (5), 506-514.

17. Kemendag. 2012 Batik cultural beauty. http://www.kemendag.go.id/files/pdf/2012/12/08/batik-id0-1354950532.pdf

18. Lorenzini, E., Calzati, V. \& Giudici, P. (2011). Territorial brands for tourism development a statistical analysis on the marche region. Annals of Tourism Research, 38, 540-560.

19. Moulard, J., Babin, B. J. \& Griffin, M. (2015). How aspects of a wine's place affect consumers' authenticity perceptions and purchase intentions: The role of country of origin and technical terroir. International Journal of Wine Business Research, 27, 61-78.

20. Park, J., Javalgi. R. \& Wachter, M. (2016). Product ethnicity and perceived consumer authenticity: the moderating role of product type. Journal of Consumer Marketing, 33/6, 58-468.

21. Pasquinelli, C. (2010). The limits of place branding for local development: The case of Tuscany and the Arnovalley brand. Local Economy, 25 (7), 558-572.

22. Porter, M. (2003). The economic performance of regions. Regional Studies, 37(6-7), 545546.

23. Simeon, M.I. \& Martone, A. (2014). Relationships between Heritage, intangible capital and cultural and creative industries in Italy: a framework analysis for urban regeneration and territorial development. Advanced Engineering Forum. 11, 149-156.

24. Suryo, U.T. (2010). Hak Kekayaan Intelektual (HKI) di Era GlobalSebuah Kajian Kontemporer. Graha IImu. Yogyakarta.

25. Sardjono, A., Prastyo, B.A. \& Larasati, D.G. (2015). Development of collective trademark for batik industry in kampung batik Laweyan (Laweyan batik's village), Solo. Indonesia Law Review, 1, 33-50. 